\title{
Perbandingan Penerapan Metode Agglomerative dengan Metode $K$-Means pada Data Curah Hujan di Wilayah Bogor
}

\author{
Hera Khoirunnisa ${ }^{1, a)}$, Budi Nurani Ruchjana ${ }^{1, b)}$, lin Irianingsih ${ }^{1, c)}$ dan Bambang \\ Suhandi ${ }^{2}$ \\ ${ }^{1}$ Departemen Matematika, Fakultas MIPA, Universitas Padjadjaran \\ ${ }^{2}$ Balai Pengelola Observatorium Nasional Kupang \\ a)email: koirunnisahera@gmail.com \\ ${ }^{b)}$ email: budi.nurani@unpad.ac.id \\ c)email: iin.irianingsih@unpad.ac.id \\ 2)email: bsuhandi63@gmail.com
}

\begin{abstract}
Abstrak
Bogor merupakan salah satu wilayah di Jawa Barat yang dijuluki sebagai kota hujan, karena memiliki curah hujan relatif lebih besar dibandingkan dengan wilayah lain, sehingga perlu dilakukan pengelompokan wilayah berdasarkan tinggi rendahnya curah hujan sebagai acuan pemerintah dalam penanganan bencana. Analisis Statistika Multivariat yang bertujuan untuk mengelompokkan objek berdasarkan karakteristiknya adalah analisis cluster. Metode dari analisis cluster yang digunakan pada penelitian ini yaitu Agglomerative dan $K$-Means. Perbedaan yang signifikan pada kedua metode tersebut terdapat pada proses pembentukan cluster. Oleh karena itu, tujuan pada penelitian ini adalah membandingkan metode yang terbaik berdasarkan kerapatan cluster. Data yang digunakan dalam penelitian ini adalah data agregat curah hujan bulanan musim basah (Desember-Januari-Februari) dari 24 stasiun pos hujan di wilayah Bogor tahun 2017-2018. Hasil penelitian menunjukkan bahwa curah hujan wilayah Kabupaten Bogor dapat dibagi menjadi 2 cluster yaitu cluster 1 kategori curah hujan sedang dan cluster 2 kategori curah hujan tinggi dengan perbandingan nilai kerapatan cluster kedua metode menghasilkan nilai yang sama yaitu sebesar 49,4\%, sehingga kedua metode tersebut baik untuk digunakan dalam pembentukan cluster curah hujan di wilayah Bogor dan bisa dijadikan sebagai rekomendasi bagi instansi terkait penggunaan data curah hujan seperti LAPAN dan BMKG.
\end{abstract}

Kata kunci: Curah Hujan, Analisis Cluster, Perbandingan Kerapatan Cluster, Agglomerative, K-Means

Abstract
Bogor is one of the regions in West Java, which is dubbed as a city of rain because it has a relatively greater
rainfall compared to other regions, so it is necessary to group regions based on high and low rainfall as a
reference for the government in handling disasters. Multivariate Statistical Analysis which aims to group
objects based on their characteristics is cluster analysis. The method of cluster analysis used in this study

e-ISSN: 2686-0341 p-ISSN: 2338-0896 
is Agglomerative and K-Means. Significant differences in the two methods are found in the cluster formation process. Therefore, the aim of this study is to compare the best method based on cluster density. The data used in this study is the aggregate data of monthly wet season rainfall (DecemberJanuary-February) from 24 rain stations in the Bogor region in 2017-2018. The results showed that the rainfall in the Bogor Regency area can be divided into 2 clusters, namely cluster 1 , the category of moderate rainfall and cluster 2 , the category of high rainfall, with the comparison of the cluster density values of the two methods producing the same value of $49.4 \%$, so both methods good for use in the formation of rainfall clusters in the Bogor region and can be used as recommendations for agencies related to the use of rainfall data such as LAPAN and BMKG.

Keywords: Rainfall, Cluster Analysis, Cluster Density Comparison, Agglomerative, K-Means

\section{Pendahuluan}

Bogor seringkali dijuluki sebagai kota hujan karena intensitas curah hujan yang terjadi di daerah tersebut relatif lebih besar dibandingkan dengan daerah lain sehingga perlu diadakannya pengelompokan curah hujan di wilayah Bogor sebagai referensi bagi pemerintah dalam penanggulangan tanggap bencana. Dengan adanya pembentukan cluster wilayah Bogor berdasarkan curah hujannya, maka penanggulangan bencana pada daerah yang termasuk cluster curah hujan yang tinggi dengan daerah yang termasuk cluster curah hujan rendah membutuhkan penanganan yang berbeda. Oleh karena itu objek pada penelitian ini adalah fenomena curah hujan bulanan pada musim basah dengan data sampel yang diambil dari 24 stasiun pos hujan di wilayah Bogor.

Salah satu teknik statistika yang digunakan untuk mengelompokkan objek berdasarkan karakteristiknya adalah analisis cluster. Analisis cluster terbagi menjadi dua metode yaitu metode hirarki dan metode non-hirarki. Metode hirarki dan metode non-hirarki yang digunakan pada penelitian ini adalah Agglomerative dan K-Means. Proses pembentukan cluster pada kedua metode tersebut sangat berbeda. Metode Agglomerative menentukan banyaknya cluster setelah semua objek tergabung dalam satu cluster utama sedangkan metode $K$-Means menentukan banyaknya cluster dilakukan sebagai proses awal. Penelitian sebelumnya menyimpulkan bahwa metode Agglomerative merupakan metode yang lebih baik jika dibandingkan dengan metode $K$-Means dalam menentukan cluster data mahasiswa pemohon beasiswa [1]. Penelitian lain mengemukakan bahwa metode $K$-Means merupakan metode terbaik dalam menentukan cluster penumpang bus Trans Jogja [2]. Oleh karena itu, pada penelitian ini penulis membandingkan metode terbaik yang membentuk cluster curah hujan di wilayah Bogor dengan membandingkan kerapatan cluster.

\section{Metode}

\section{Analisis Cluster}

Analisis cluster adalah salah satu teknik analisis statistika multivariat yang bertujuan untuk mengelompokkan objek berdasarkan karakteristik dari setiap kelompok tertentu. Hasil dari pengelompokan suatu objek harus menunjukkan kehomogenan yang tinggi di dalam satu cluster dan keheterogenan yang tinggi antar cluster. Metode analisis cluster secara umum terbagi menjadi 2 yaitu metode hirarki dan metode non-hirarki [3]. 


\section{Metode dalam Analisis Cluster}

a. Metode Agglomerative

Metode Agglomerative merupakan metode analisis cluster hirarki yang dimulai dengan menentukan masing-masing objek sebagai cluster yang berbeda. Dua objek yang memiliki kemiripan digabungkan menjadi cluster yang baru. Proses tersebut dilakukan berulang sampai semua cluster bergabung dalam satu cluster. Hasil akhir dari metode Agglomerative ditampilkan dalam bentuk diagram pohon dua dimensi atau disebut dendogram. Terdapat beberapa cara perhitungan jarak kesamaan antar objek pada metode Agglomerative, pada penelitian ini perhitungan jarak kesamaan antar objek menggunakan metode Complete Linkage [3].

Complete Linkage adalah algoritma cluster hirarki yang mendefinisikan kesamaan objek sebagai jarak maksimum antar objek tunggal dalam satu cluster dan objek tunggal lainnya, $\mathbf{D}=\left\{d_{i k}\right\}$ atau dalam arti lain jarak antara dua cluster $U$ dan $V$ didefinisikan sebagai jarak maksimum diantara titik di $U$ dan titik di $V$ dengan rumus:

$$
d_{(U V) W}=\max \left(d_{U W}, d_{V W}\right)
$$

dengan:

$d_{U W} \quad$ : Jarak antar objek pada cluster $U$ dan cluster $W$

$d_{V W} \quad$ : Jarak antar objek pada cluster $V$ dan cluster $W$

Pada proses analisis cluster dengan metode Agglomerative diperlukan pemilihan cluster untuk menentukan jumlah cluster optimum. Pemilihan jumlah cluster optimum dapat digunakan dengan menggunakan kriteria nilai Pseudo F statistics dengan rumus:

$$
\text { Pseudo F statistics }=\frac{R^{2} / k-1}{1-R^{2} / N-k}
$$

Dan

$$
\begin{gathered}
R^{2}=\frac{\text { JKTotal }-J \text { KDalam Kelompok }}{\text { JKTotal }} \\
\text { JKTotal }=\sum_{i=1}^{n} \sum_{p=1}^{c} \sum_{j=1}^{k}\left(x_{i p j}-\bar{x}\right)^{2} \\
\text { JKDalam Kelompok }=\sum_{i=1}^{n} \sum_{p=1}^{c} \sum_{j=1}^{k}\left(x_{i p j}-\bar{x}_{j}\right)^{2}
\end{gathered}
$$

dengan:

$x_{i p j} \quad$ : objek ke-i pada variabel ke-p cluster ke-j

$\bar{x} \quad$ : rata-rata seluruh sampel

$\bar{x}_{j} \quad$ : rata-rata sampel pada cluster ke-j

Nilai Pseudo F statistics tertinggi menunjukkan bahwa jumlah kelompok data telah optimal [4].

\section{b. Metode K-Means}

Istilah $K$-Means digunakan untuk menjelaskan sebuah algoritma yang memiliki centroid terdekat di setiap cluster [3]. Penentuan centroid awal dilakukan secara acak dan ditentukan partisi objek sebanyak $k$ 
cluster, kemudian menghitung centroid ke-i variabel ke-p berikutnya menggunakan persamaan sebagai berikut:

$$
v_{i p}=\frac{\sum_{i=1}^{n} x_{i p}}{n_{p j}}, i=1,2, \ldots, n
$$

dengan:

$v_{i p} \quad$ : centroid ke-i variabel ke- $p$

$x_{i p} \quad$ : objek pengamatan ke-i variabel ke- $p$

$n_{p j} \quad$ : banyaknya objek pada variabel ke-p cluster ke-j

\section{Uji Asumsi Analisis Cluster}

a. Uji Kecukupan Sampel

Uji kecukupan sampel bertujuan untuk menguji apakah sampel dianggap cukup untuk dianalisis lebih lanjut. Uji kecukupan sampel dapat dilihat dari:

a. Indeks Kaiser Meyer Olkin (KMO) yang digunakan untuk meneliti apakah data tersebut layak dianalisis atau tidak dengan menggunakan rumus:

$$
K M O=\frac{\sum_{\mathrm{p} \neq \mathrm{q}}^{\mathrm{c}} r_{\mathrm{pq}}{ }^{2}}{\sum_{\mathrm{p} \neq \mathrm{q}}^{\mathrm{c}} r_{\mathrm{pq}}{ }^{2}+\sum_{\mathrm{p} \neq \mathrm{q}}^{\mathrm{c}} b_{\mathrm{pq}}{ }^{2}}
$$

dengan:

$r_{p q} \quad:$ koefisien korelasi sederhana antara variabel ke- $p$ dan variabel ke- $q$

$b_{p q} \quad$ : koefisien korelasi parsial antara variabel ke- $p$ dan variabel ke- $q$.

Sampel dikatakan layak dianalisis jika nilai KMO $\geq 0,5$ [5].

b. Measure of Sampling Adequency (MSA) yang digunakan untuk mengetahui apakah variabel memadai untuk dianalisis lebih lanjut. Jika setiap variabel memiliki nilai MSA $\geq 0,50$ maka variabel tersebut layak untuk dianalisis [5].

\section{b. Uji Multikolinearitas}

Uji multikolinearitas bertujuan untuk menguji apakah ada korelasi yang tinggi dari variabel yang diikut sertakan atau tidak. Variabel analisis cluster tersebut disebuk baik jika antar variabel bebas tidak terjadi multikolinearitas. Salah satu cara untuk mengetahui ada tidaknya multikolinearitas dapat dilihat dari nilai Variance Inflaction Factor (VIF) dengan rumus sebagai berikut:

$$
V I F=\frac{1}{1-R_{p}^{2}}
$$

dengan:

$R_{p}{ }^{2} \quad$ : koefisien determinasi antara variabel bebas ke- $p$ dengan variabel bebas lainnya.

Jika nilai VIF berada pada angka 5 atau 10 maka terindikasi terjadinya multikolinearitas [6].

\section{Jarak Euclid}

Jarak antar objek ke-i dan objek ke-k disimbolkan dengan $d_{i k}$ pada variabel ke- $p$. Perhitungan jarak Euclid dari dua objek sebanyak $p$ variabel menggunakan persamaan sebagai berikut: 


$$
d_{i k}=\sqrt{\sum_{p=1}^{c}\left|x_{i p}-x_{k p}\right|^{2}}
$$

dengan:

$d_{i k} \quad$ : jarak Euclid pada objek ke-i dan objek ke-k

$x_{i p} \quad:$ data dari objek ke-i variabel ke- $p$

$x_{k p} \quad:$ data dari objek ke-k variabel ke- $p$

Semakin dekat jarak Euclid semakin mirip objek data tersebut [3].

\section{Kerapatan Cluster}

Prinsip dalam membentuk cluster yang baik adalah kesamaan antar objek dalam cluster yang maksimum dan kesamaan antar objek pada cluster berbeda yang minimum. Salah satu metode untuk menentukan cluster terbaik adalah dengan menghitung kerapatan cluster. Cluster yang baik memiliki nilai variansi dalam cluster yang minimum dan variansi antar cluster yang maksimum [7].

Jika diberikan cluster $C_{j}$ sebanyak $k$ cluster maka untuk mencari nilai variansi cluster ke-j $\left(s_{j}{ }^{2}\right)$ menggunakan rumus:

$$
s_{j}^{2}=\frac{1}{n_{j}-1} \sum_{i=1}^{n}\left(x_{j i}-\bar{x}_{j}\right)^{2} ; i=1,2, \ldots, n
$$

karena $\left(\boldsymbol{s}_{\boldsymbol{j}}{ }^{2}\right)$ telah diketahui, untuk mencari variansi dalam cluster $\left(s_{w}{ }^{2}\right)$ dapat dihitung menggunakan rumus:

$$
s_{w}^{2}=\frac{1}{k} \sum_{j=1}^{k} s_{j}^{2}
$$

Variansi antar cluster $\left(s_{b}{ }^{2}\right)$ digunakan untuk mengukur variabilitas dari rata-rata setiap kelompok berdasarkan rata-rata global $(\bar{x})$. Rumus variansi antar cluster $\left(s_{b}{ }^{2}\right)$ sebagai berikut:

$$
s_{b}^{2}=\frac{1}{k-1} \sum_{j=1}^{k} n_{j}\left(\bar{x}_{j}-\bar{x}\right)^{2}
$$

dengan:

$x_{j i} \quad$ : anggota ke-i setiap cluster

$\bar{x}_{j} \quad$ : rata-rata cluster ke-j

$n_{j} \quad$ : banyaknya anggota cluster ke-j

$k \quad$ : banyaknya cluster

$\bar{x} \quad$ : anggota ke-i setiap cluster

Cluster yang baik memiliki nilai $\left(s_{w}{ }^{2}\right)$ yang minimum dan nilai $\left(s_{b}{ }^{2}\right)$ yang maksimum [7], artinya cluster yang baik memiliki nilai minimum Rasio dengan rumus:

$$
\text { Rasio }=\frac{s_{w}^{2}}{s_{b}^{2}}
$$




\section{Hasil dan Diskusi}

Data yang digunakan dalam penelitian ini adalah data agregat curah hujan bulanan pada musim basah periode Desember-Januari-Februari (DJF). Data tersebut diperoleh dari Badan Pusat Statistik Kabupaten Bogor tahun 2018 [8]. Data agregat curah hujan bulanan di wilayah Bogor pada 24 stasiun pos hujan adalah sebagai berikut:

$X_{1} \quad$ : data agregat curah hujan bulan Desember tahun 2017

$X_{2} \quad$ : data agregat curah hujan bulan Januari tahun 2018

$X_{3} \quad$ : data agregat curah hujan bulan Februari tahun 2018

Contoh data penelitian disajikan pada Tabel 1 berikut ini.

Tabel 1. Contoh Data Penelitian Agregat Curah Hujan Kab. Bogor

\begin{tabular}{llll}
\hline Stasiun Pos Hujan & & \multicolumn{2}{l}{ Agregat Curah Hujan Bulanan (mm) } \\
\hline \multirow{2}{*}{ Leuwi Liang } & 230 & Jan-18 & Feb-18 \\
Dramaga & 181 & 293 & 178 \\
Empang & 190 & 190 & 364 \\
Ciawi & 225 & 165 & 473 \\
Gadog & 292 & 316 & 743 \\
Dayeuh & 325 & 266 & 832 \\
Cariu & 141 & 168 & 394 \\
Klapanunggal & 309 & 283 & 351 \\
Ciriung & 209 & 144 & 423 \\
Parung Panjang & 101 & 219 & 441 \\
Jasinga & 298 & 335 & 316 \\
Cibalagung & 225 & 281 & 203 \\
... & & & 394 \\
& & & \\
\hline
\end{tabular}

Sumber: BPS Kab. Bogor (2018)

\section{Hasil Uji Asumsi Analisis Cluster}

Pengolahan data untuk uji asumsi Analisis Cluster dilakukan menggunakan software RStudio menggunakan library dengan beberapa command diantaranya:

$>$ library(cluster)

>library(dendextend)

>library(factoextra)

>library(faraway)

$>$ library(readxl)

$>$ library(stats)

$>$ library(psych) 


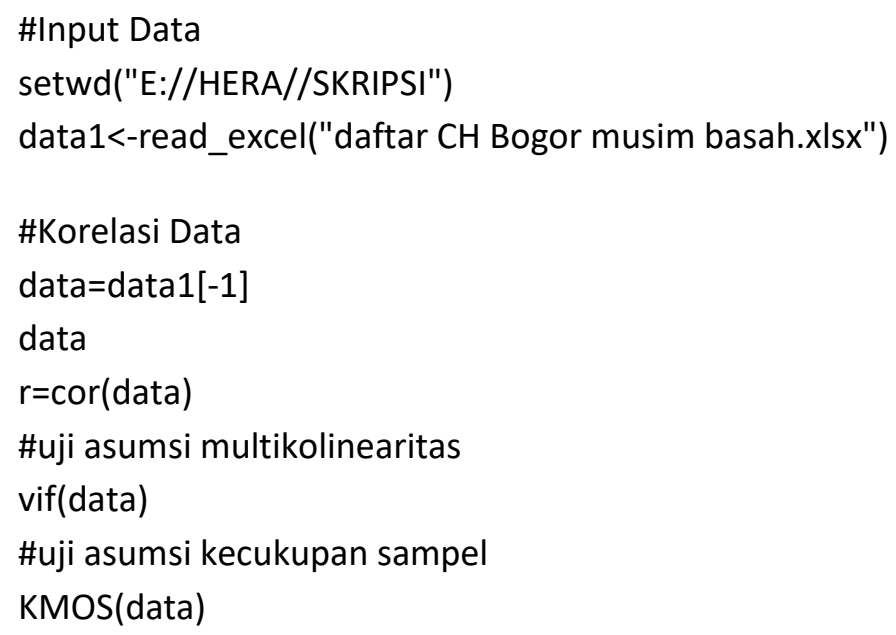

Hasil uji yang diperoleh disajikan sebagai berikut:

\section{a. Hasil Uji Kecukupan Sampel}

Uji kecukupan sampel bertujuan untuk menguji apakah sampel dan variabel yang digunakan cukup untuk dianalisis, dapat dilihat dari nilai indeks KMO dan MSA yang ditampilkan pada Tabel 2.

Tabel 2. Hasil uji KMO dan MSA

\begin{tabular}{lcccc}
\hline \multicolumn{2}{l}{ Kaiser Meyer Olkin (KMO) } & \multicolumn{3}{l}{0,57494} \\
\hline Measure of Sampling & $\boldsymbol{X}_{\mathbf{1}}$ & $\boldsymbol{X}_{\mathbf{2}}$ & $\boldsymbol{X}_{\mathbf{3}}$ \\
\cline { 3 - 5 } Adequency (MSA) & & 0,55 & 0,56 & 0,74 \\
\hline
\end{tabular}

Berdasarkan Tabel 2 dapat dilihat bahwa nilai KMO sebesar 0,57494 dan nilai MSA masing-masing variabel $>0,5$. Karena nilai KMO >0,5 dan nilai MSA >0,5 maka sampel dan variabel yang digunakan pada penelitian ini layak untuk dianalisis lebih lanjut.

\section{b. Hasil Uji Multikolinearitas}

Uji multikolinearitas bertujuan untuk mengetahui ada tidaknya korelasi yang sangat kuat antar variabel penelitian. Untuk mendeteksi adanya multikolinearitas menggunakan nilai Variance Inflaction Factor (VIF) yang ditampilkan dalam Tabel 3.

Tabel 3. Hasil uji nilai VIF

\begin{tabular}{cccc}
\hline \multirow{2}{*}{ Nilai VIF } & $\boldsymbol{X}_{\mathbf{1}}$ & $\boldsymbol{X}_{\mathbf{2}}$ & $\boldsymbol{X}_{\mathbf{3}}$ \\
\cline { 2 - 4 } & 1,797 & 1,688 & 1,135 \\
\hline
\end{tabular}

Berdasarkan Tabel 3 dapat dilihat bahwa nilai VIF dari semua variabel kurang dari 5 atau 10, itu artinya tidak terdapat multikolinearitas pada data penelitian. 


\section{Proses Pembentukan Cluster}

\section{a. Pembentukan Cluster Metode Agglomerative}

Pembentukkan cluster metode Agglomerative dimulai dengan menghitung jarak antar objek menggunakan persamaan (1) dilanjutkan dengan menggabungkan objek yang memiliki kedekatan jarak. Contoh perhitungan kedekatan jarak pada stasiun pos hujan Leuwi Liang dengan stasiun pos hujan Dramaga sebagai berikut:

$$
\begin{aligned}
& d_{12}=\sqrt{\left(x_{11}-x_{21}\right)^{2}+\left(x_{12}-x_{22}\right)^{2}+\left(x_{13}-x_{23}\right)^{2}} \\
& d_{12}=\sqrt{(230-181)^{2}+(293-190)^{2}+(178-364)^{2}} \\
& d_{12}=218,188 \mathrm{~mm}
\end{aligned}
$$

sedangkan untuk perhitungan kedekatan jarak stasiun pos hujan Leuwi Liang dengan stasiun pos hujan Empang sebagai berikut:

$$
\begin{aligned}
& d_{13}=\sqrt{\left(x_{11}-x_{31}\right)^{2}+\left(x_{12}-x_{32}\right)^{2}+\left(x_{13}-x_{33}\right)^{2}} \\
& d_{13}=\sqrt{(230-190)^{2}+(293-199)^{2}+(178-473)^{2}} \\
& d_{13}=312,188 \mathrm{~mm} .
\end{aligned}
$$

Dari contoh tersebut, dapat dilihat hasil perhitungan kedekatan jarak antara stasiun pos hujan Leuwi Liang dengan stasiun pos hujan Dramaga adalah 218,188 mm sedangkan jarak antara stasiun pos hujan Leuwi Liang dengan stasiun pos hujan Empang adalah 312,188 mm. Hal tersebut menunjukkan bahwa stasiun pos hujan Leuwi Liang memiliki karakteristik yang lebih mirip dengan Stasiun pos hujan Dramaga jika dibandingkan dengan stasiun pos hujan Empang. Perhitungan dilanjutkan sampai semua objek bergabung dalam satu cluster utama.

Pemilihan cluster optimum menggunakan nilai Pseudo F statitistics yang ditampilkan pada Tabel 4.

Tabel 4. Perbandingan Pseudo F Statistics

\begin{tabular}{ccc}
\hline Banyaknya Cluster & R-Square & $\begin{array}{c}\text { Pseudo } \boldsymbol{F} \\
\text { Statistics }\end{array}$ \\
\hline 2 & 0,14909 & 3,85459 \\
3 & 0,24575 & 3,42111 \\
4 & 0,27677 & 2,55129 \\
5 & 0,27842 & 1,83273 \\
6 & 0,28545 & 1,43816 \\
\hline
\end{tabular}

Berdasarkan Tabel 4 dapat ditunjukkan nilai Pseudo F statistics tertinggi adalah 3,85459 dengan jumlah cluster yang terbentuk sebanyak 2 cluster. Oleh karena itu, cluster optimum stasiun pos hujan wilayah Bogor sebanyak 2 cluster dengan hasil dendogram pada Gambar 1. 


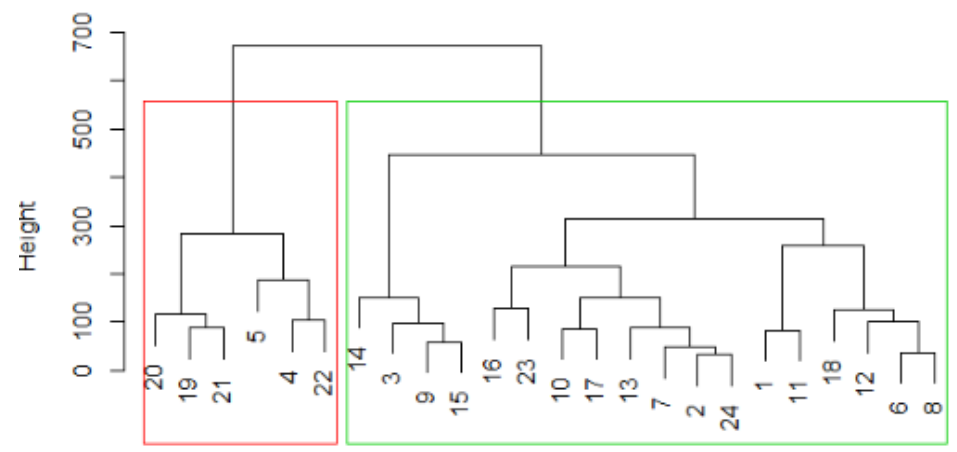

Gambar 1. Cluster dendogram

Berdasarkan Gambar 1 klasifikasi pembagian stasiun pos hujan yang masuk ke dalam cluster dapat ditampilkan dalam Tabel 5.

Tabel 5. Anggota cluster yang terbentuk metode Agglomerative

\begin{tabular}{cl}
\hline Cluster & \multicolumn{1}{c}{ Stasiun Pos Hujan } \\
\hline Cluster 1 & $\begin{array}{l}\text { Leuwi Liang, Dramaga, Dayeuh, Cariu, Klapanunggal, Parung Panjang, Jasinga, Cibalagung, } \\
\text { Citayam, Beji Depok, Tanjung Rasa, Tunggilis, Kebun Raya, Cimanggu, Empang, Ciriung, } \\
\\
\text { Lanud Atang Sanjaya, dan Depok BMKG. }\end{array}$ \\
\hline
\end{tabular}

Berdasarkan Tabel 5 dapat dilihat bahwa cluster 1 sebanyak 18 stasiun pos hujan yang memiliki ratarata agregat curah hujan bulanan sebesar $254,20 \mathrm{~mm}$ dengan kategori cluster curah hujan sedang. Cluster 2 sebanyak 6 stasiun pos hujan yang memiliki rata-rata agregat curah hujan bulanan sebesar 439,94 mm dengan kategori cluster curah hujan tinggi.

\section{b. Pembentukan Cluster Metode K-Means}

Pada pembentukan cluster metode Agglomerative, cluster telah optimum sebanyak 2 cluster. Berdasarkan hal tersebut, pembentukan cluster metode $K$-Means sebanyak 2 cluster. Inisiasi centroid $K$ Means dilakukan secara acak dengan $C_{1}$ adalah centroid cluster 1 dan $C_{2}$ adalah centroid cluster 2 . Perhitungan jarak objek terhadap stasiun pos hujan sesuai persamaan (9). Contoh perhitungan jarak stasiun pos hujan Leuwi Liang dengan $\mathrm{C}_{1}$ berikut:

$$
\begin{aligned}
\text { Leuwi Liang } & =\sqrt{\left(x_{11}-225\right)^{2}+\left(x_{12}-177\right)^{2}+\left(x_{13}-180\right)^{2}} \\
& =\sqrt{(230-225)^{2}+(293-177)^{2}+(178-180)^{2}} \\
& =116,12 \mathrm{~mm} .
\end{aligned}
$$

Perhitungan jarak stasiun pos hujan Leuwi Liang dengan $\mathrm{C}_{2}$ sebagai berikut:

$$
\begin{aligned}
\text { Leuwi Liang } & =\sqrt{\left(x_{11}-292\right)^{2}+\left(x_{12}-177\right)^{2}+\left(x_{13}-180\right)^{2}} \\
& =\sqrt{(230-292)^{2}+(293-177)^{2}+(178-180)^{2}} \\
& =657,33 \mathrm{~mm}
\end{aligned}
$$

Stasiun pos hujan Leuwi Liang memiliki jarak terdekat ke $\mathrm{C}_{1}$ yang berarti bahwa stasiun pos hujan Leuwi Liang masuk ke cluster 1 . Demikian seterusnya sampai stasiun pos hujan ke-24 tergabung ke dalam cluster sesuai jarak terdekat. Plot cluster metode K-Means ditampilkan pada Gambar 2. 


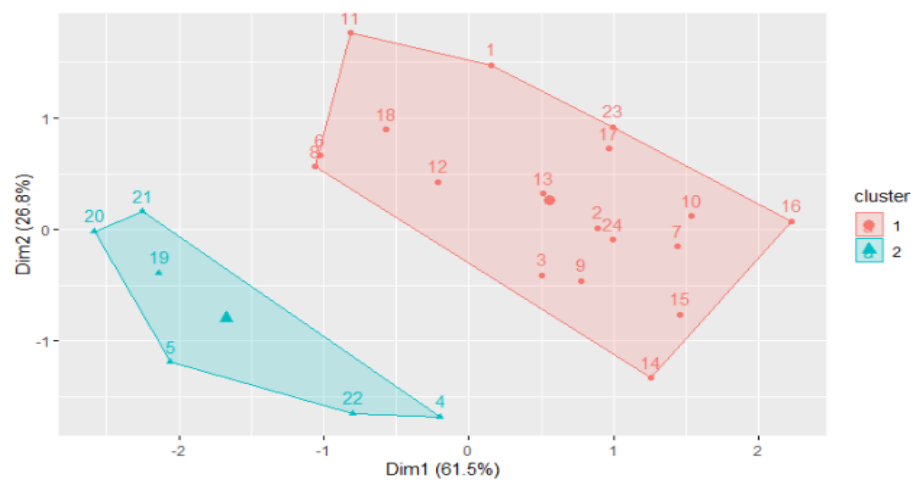

Gambar 2. Plot cluster metode K-Means

Berdasarkan Gambar 2. klasifikasi pembagian stasiun pos hujan yang masuk ke dalam cluster dapat ditampilkan dalam Tabel 6.

Tabel 6. Anggota cluster yang terbentuk metode $K$-Means

\begin{tabular}{cl}
\hline Cluster & \multicolumn{1}{c}{ Stasiun Pos Hujan } \\
\hline Cluster 1 & Leuwi Liang, Dramaga, Dayeuh, Cariu, Klapanunggal, Parung Panjang, Jasinga, Cibalagung, \\
& $\begin{array}{l}\text { Citayam, Beji Depok, Tanjung Rasa, Tunggilis, Kebun Raya, Cimanggu, Empang, Ciriung, } \\
\text { Lanud Atang Sanjaya, dan Depok BMKG. }\end{array}$ \\
Cluster 2 & Ciawi, Gadog, Citeko, Naringgul, Gunung Mas, dan Katulampa. \\
\hline
\end{tabular}

Pada Tabel 6 dapat dilihat bahwa cluster 1 sebanyak 18 stasiun pos hujan yang memiliki rata-rata agregat curah hujan bulanan sebesar 254,20 mm dengan kategori cluster curah hujan sedang. Cluster 2 sebanyak 6 stasiun pos hujan yang memiliki rata-rata agregat curah hujan bulanan sebesar 439,94 $\mathrm{mm}$ dengan kategori cluster curah hujan tinggi.

Berdasarkan hasil anggota cluster yang terbentuk diperoleh bahwa pembentukan cluster metode Agglomerative dengan metode $K$-Means menghasilkan anggota yang sama pada kategori cluster yang sama dengan rata-rata curah hujan bulanan setiap cluster yang sama pula. Oleh karena itu, baik metode Agglomerative maupun metode K-Means menghasilkan 2 cluster, cluster 1 stasiun pos hujan dengan kategori curah hujan sedang dan cluster 2 stasiun pos hujan dengan kategori curah hujan tinggi.

Sebaran cluster stasiun pos metode Agglomerative dan metode K-Means dapat ditampilkan dalam peta wilayah Bogor pada Gambar 3.

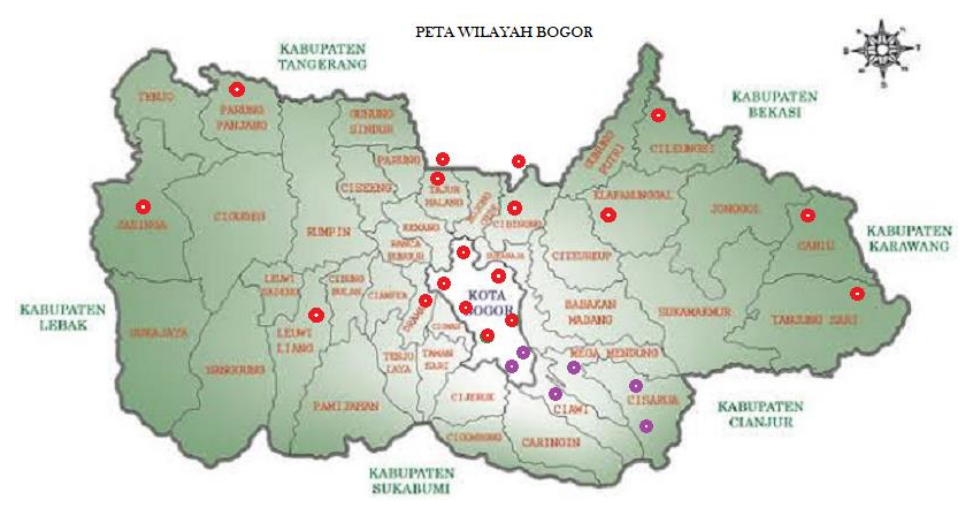

Gambar 3. Sebaran cluster pada peta wilayah Bogor 
Keterangan:

- Cluster 1

- Cluster 2

\section{c. Perbandingan Kerapatan Cluster}

Alat perbandingan untuk menentukan cluster terbaik adalah perhitungan kerapatan cluster. Setelah dilakukan pembentukan cluster menggunakan metode Agglomerative dan metode $K$-Means, hasil yang diperoleh ternyata anggota cluster yang dihasilkan oleh kedua metode tersebut sama. Sehingga kategori cluster untuk metode Agglomerative dan metode $K$-Means pun sama. Selanjutnya dihitung variansi setiap cluster yang ditampilkan pada Tabel 7.

Tabel 7. Variansi setiap cluster

\begin{tabular}{cc}
\hline Cluster & Variansi \\
\hline Cluster 1 & 34273,57 \\
Cluster 2 & 170524,98 \\
\hline
\end{tabular}

Berdasarkan nilai variansi setiap cluster pada Tabel 7 dapat dihitung nilai variansi dalam kelompok sebagai berikut:

$s_{w}^{2}=\frac{1}{2}(34272,57+170524,98)$

$s_{w}^{2}=102399,28$.

Setelah dihitung variansi dalam cluster, maka dihitung variansi antar cluster $\left(s_{b}{ }^{2}\right)$ dengan terlebih dahulu menghitung rata-rata keseluruhan dari setiap cluster sebagai berikut:

$\bar{x}=\frac{1}{2}(254,20+439,94)$

$\bar{x}=347,07$

maka perhitungan variansi antar cluster $\left({s_{b}}^{2}\right)$ adalah sebagai berikut:

$s_{b}{ }^{2}=\frac{1}{2-1}[(254,20-347,07)+(439,94-347,07)]$

$s_{b}^{2}=206997,74$

selanjutnya dihitung nilai rasio dari variansi dalam cluster $\left(s_{w}{ }^{2}\right)$ dengan variansi antar cluster $\left({s_{b}}^{2}\right)$ sebagai berikut:

$$
\text { Rasio }=\frac{s_{w}{ }^{2}}{{s_{b}}^{2}}=\frac{102399,28}{206997,74}=0,4946879
$$

Berdasarkan perhitungan hasil bahwa anggota cluster untuk kedua metode sama pada masingmasing cluster, maka kedua metode tersebut menghasilkan nilai perbandingan cluster yang sama yaitu sebesar $49,4 \%$ dengan perbedaan yang signifikan terletak pada proses pembentukan awal cluster.

\section{Kesimpulan}

Berdasarkan hasil dari pembahasan dapat disimpulkan bahwa pembentukan cluster metode Agglomerative dan metode $K$-Means pada 24 stasiun pos hujan wilayah Bogor dengan menggunakan data 
agregat curah hujan bulanan pada musim basah periode Desember tahun 2017 sampai Februari tahun 2018 terbentuk sebanyak 2 cluster, yaitu cluster 1 berupa kelompok stasiun pos hujan wilayah Bogor dengan kategori curah hujan sedang dan cluster 2 berupa kelompok stasiun pos hujan wilayah Bogor dengan kategori curah hujan tinggi. Setelah dilakukan perbandingan menggunakan kerapatan cluster, hasil kerapatan cluster metode Agglomerative dan metode $K$-Means untuk data curah hujan di wilayah Bogor menghasilkan nilai yang sama. Oleh karena itu, kedua metode dalam analisis cluster dapat digunakan untuk menentukan kelompok lokasi-lokasi curah hujan di wilayah Bogor.

\section{Ucapan Terima Kasih}

Penulis mengucapkan terima kasih kepada Rektor Universitas Padjadjaran yang telah memberikan dukungan dana penelitian melalui Academic Leadership Grant tahun 2020 dengan nomor kontrak 1427/UN6.3.1/LT/2020 untuk diseminasi hasil penelitian dosen dan mahasiswa.

\section{Referensi}

[1] Satria, F. \& Aziz, R. A., "Perbandingan Kinerja Metode Ward dan K-Means Dalam Menentukan Cluster Data Mahasiswa Pemohon Beasiswa”, Jurnal TIM Darmajaya, pp. 12-26, 2016.

[2] Zahrotun, L., "Analisis Pengelompokan Jumlah Penumpang Bus Trans Jogja Menggunakan Metode Clustering K-Means dan Agglomerative Hierarchical Clustering (AHC)", Jurnal Informatika, Vol. 9, pp. 1039-1047, 2015.

[3] Johnson, R. A. \& Wichern, D. W., “Applied Multivariate Statistical Analysis”, Penerbit Pearson, New Jersey, 2007.

[4] Putri, M. M. \& Fithriasari, K., “Pengelompokan Kabupaten/Kota di Jawa Timur Berdasarkan Indikator Kesehatan Masyarakat Menggunakan Metode Kohonen SOM dan K-Means", Jurnal Sains dan Seni ITS, Vol. 4 No. 1, pp. 13-18, 2015.

[5] Hair, J. F., Black, W. C., Babin, B. J. \& Anderson, R. E., "Multivariate Data Analysis", Penerbit Pearson Prentice Hall, New Jersey, 2010.

[6] James, G., Witten, D., Hastie, T. \& Tibshirani, R., "An Introduction to Statistical Learning”, Penerbit Springer, New York, 2013.

[7] Barakbah, A. R. \& Arai, K., "Determining Constraint of Moving Variance to Find Global Optimum and Make Automatic Clustering", Industrial Electronics Seminar (IES), pp. 409-413, 2004.

[8] http://bogorkab.bps.go.id/ [diakses 01 November 2017].

[9] https://www.bogorchannel.com, [diakses 01 November 2017] 